\title{
The Nexus between Infrastructure Investment and Economic Growth in the Mexican Urban Areas
}

\author{
Vicente German-Sotoํㅜ, Héctor A. Barajas Bustillos² \\ ${ }^{1}$ Facultad de Economía, Universidad Autónoma de Coahuila, Saltillo, México \\ ${ }^{2}$ Instituto de Ciencias Sociales y Administración, Universidad Autónoma de Ciudad Juárez, Ciudad Juárez, \\ México \\ Email: vicentegerman@uadec.edu.mx, hbarajas@uacj.mx
}

Received 16 October 2014; revised 25 November 2014; accepted 10 December 2014

Copyright (C) 2014 by authors and Scientific Research Publishing Inc.

This work is licensed under the Creative Commons Attribution International License (CC BY).

http://creativecommons.org/licenses/by/4.0/

(c) (i) Open Access

\section{Abstract}

The relationship between infrastructure investment and economic growth is explored for the main urban areas of Mexico during the period 1985-2008. The methodology consists of a production function estimated by means of panel data techniques that include distributed effects in time. The findings highlight that the economic impact from infrastructure investment is effectively spread through time and cannot only be contemporaneous. This result suggests long-run effects. Moreover, the empirical estimates are according to the urban areas' economic performance: Where major infrastructure provision exists, higher rates of growth are also taking place. Conclusions highlight that if infrastructure provision is not enough it could be a restriction for growth.

\section{Keywords}

\section{Infrastructure Investment, Economic Growth, Urban Economics}

\section{Introduction}

Infrastructure investment and economic growth are often narrowly linked through a positive relationship in the long run (Aschauer, [1] and Aschauer [2]). This means that greater endowments of infrastructure are associated with greater levels of productivity. However, this process is not necessarily linear and contemporaneous because the effects are disseminated through time (Hirschmann [3]; Nijkamp and Ubbels [4]; among others).

The Organisation for Economic Co-Operation and Development (OECD) [5] defines infrastructure as the equipment of industries and firms (stock of capital), public services (electric energy, water supply and drainage ser- 
vices), public endowments (roads and highways) and airports, hotels and other services. Under this conception, the purpose of creating the infrastructure is to establish ideal conditions for business that stimulate economic growth and increase productivity and employment. Therefore, the infrastructure has the potential to elevate the income and augment the social and economic opportunities in those regions or countries with a better endowment.

In Mexico, as well as in other countries, the differences in terms of economic growth are quite accentuated and they can limit the well-being of some groups of inhabitants, excluding them from the benefits of the development. To confront this situation, governments are often obligated to establish programs of regional policy aimed to stimulate the creation of new employment and thus to increase the regional productivity. However, these actions are not without some costs because to fulfill this objective it is necessary to assign national resources to those priority areas. In brief, just those factors facilitating the regional growth should be aimed to reduce the inequalities.

Since the opening of trade and the decentralization process, some Mexican regions have increased their human capital, improved their basic infrastructure and concentrated on great industrial plants; as a consequence, they have been able to overcome some regional growth barriers (Chiquiar [6]). However, since the opening of trade, the regional inequalities have also increased because the major growth exhibited in some regions was felt as deepening inequalities in the other regions (Buitrago [7]; Garduño [8]).

The reduction of inequalities should be achieved through customized public policies based on the particular conditions of the regions (Calderón Villarreal [9]), but the government should also participate in the economy by implementing compensatory policies to diminish the differences (Ocegueda-Hernández [10]; De Hoyos and Lustig [11]). As a good example of regional policy, the creation of basic infrastructure stands out because it is a factor in which the government can intervene through public expenditure.

The aim of this work is investigate the role of infrastructure in the economic growth differences at the urban areas level of Mexico. The urban areas level allows us to measure the integration of metropolitan zones, with a major number of observations and greater samples, and to improve the efficiency of the methodologies.

The hypothesis assumes that several infrastructure variables interact with economic growth from a dynamic perspective in which the impact of the first variable on the second has a temporal lag. Therefore, a negative effect of the infrastructure is initially expected, because resources invested in infrastructure first inhibit economic growth; subsequently, the effects become positive, when the infrastructure investments start to generate growth.

The empirical evidence on this argument is supported by an econometric specification better adjusted to the theories, highlighting that economic growth is generated by factors of endogenous production in the long run. The methodology of estimation, moreover, allows us to overcome some econometric details regularly present in this kind of work, such as first-order autocorrelation, regional heterogeneity and the potential problems of multicollinearity.

The empirical findings suggest a positive relationship between growth and infrastructure investment for Mexico's urban areas. This link is clearer when lagged values of the inputs are included in the model. The results also highlight the evident heterogeneity between urban areas, because important differences in the impacts of infrastructure are estimated between the cities with the greatest income and those with the lowest income.

The next second section reviews the empirical evidence related to growth and infrastructure investment, while the third section reveals the econometric specification. The fourth section describes the data and explains the criteria for the sample selection. The regression results are analyzed in the fifth section and the last section presents the concluding remarks.

\section{Explorations of the Infrastructure-Economic Growth Relationship: A Review}

Several nations have used infrastructure investments extensively as instruments of policies and regional development programs since Aschauer's [1] evidence that infrastructure investment positively and significantly affects productivity. The investments and public expenditure constitute solid policies by means of which countries, regions and urban areas can promote economic growth, in line with the suggestions of Barro [12].

Some examples of important policy actions are the development of cities in Malaysia and Thailand, the program of transport in lagging regions of the northeast of Brazil and the migration programs from densely settled islands in Indonesia (Lall [13]). From a theoretical perspective, infrastructure constitutes an intermediate public good that makes an efficient process of production possible. Puga [14] indicates that all policies directed to- 
wards augmenting the infrastructure stock in the more lagged regions will improve the local firms' productivity and will also attract new firms, facilitating the sub-national areas' growth.

Research on the links between physical equipment and economic growth, according to Lall [13], first appeared, among others, in the works of Nurske [15], Hirschman [16] and Nadiri [17]. However, just in the last decades, a great amount of empirical applications have been seen concerning this nexus. The first works on this new stage base their studies on an aggregated production function in which infrastructure is recognized as an input, although the results are inconclusive because of some econometric problems of unit roots and spurious correlations that were not attended to at that moment (Sánchez-Robles [18]; Lall [13]). Some authors suggest applying regression equations in first differences or including fixed effects, but there is a loss of statistical significance (Evans and Karras [19]; Holtz-Eakin and Schwartz [20]); others augment the sample, but negative and not significant coefficients are obtained (Devarajan et al. [21]; Otto and Voss [22]). Aschauer [2] augments the temporal period in his studies, includes human capital and considers dynamic effects in his equations; as a result, the estimates are improved when the coefficients become positive and significant.

Some recent works incorporate panel information, stochastic analysis and spatial econometric techniques and obtain improved results in accordance with the theoretical expectation. In this respect, Zhang [23] uses spatial econometric techniques and demonstrates that transport infrastructure and economic growth create a spatial cluster in China. Mizutani and Tanaka [24] find that infrastructure investment by the national government accelerates that investment realized by the governments of the Japanese prefectures. Pereira and Andraz [25] highlight that investment in highways positively affects the aggregated production in a majority of the states of the US Herrerías and Orts [26] provide evidence on equipment investment and human capital as determinant factors of the product growth of China in the long run.

The last two works build their results in an autoregressive vectors structure, suggesting that the time effect constitutes a potential source that should be taken into account in the economic growth and infrastructure relationship.

As far as Mexico is concerned, the empirical evidence is generally in accordance with the theoretical expectation. Feltenstein and Ha [27] conclude that the road infrastructure is not productive; however, Fuentes [28] and Fuentes and Mendoza Cota [29] report positive effects of the electricity infrastructure, transport and telecommunications. Garduño [8] finds high rates of growth in municipalities linked to the exportation industry after the North American Free Trade Agreement and they are also superior to those of other regions. Noriega and Fontela [30] estimate positive effects from electricity and roads on the long-run economic growth, but they consider a lag of eleven years, indicating that the nexus with economic growth should not necessarily be contemporaneous.

Other studies adjust their estimates to take into account the time effect; however, the infrastructure impact is considered as contemporaneous or with a one-lag year. According to Lächler and Aschauer [31] and Noriega and Fontela [30], the augments in the infrastructure investment are not automatically reflected in greater economic growth. This fact reveals the existence of temporal effects that can be longer than one year.

\section{Methodology and Econometric Specification}

We start from the traditional idea of considering a production schema, as presented by Holtz-Eakin [32]. The author assumes a Cobb-Douglas production function to study the relationship between the public capital accumulation and the productivity in the private sector in the US. The formal expression of this link is generally defined as follows:

$$
f(q)=\alpha_{0} \prod_{k=1}^{K} x_{k}^{\beta_{k}}, \text { for all } \beta_{k}>0
$$

This expression has suitable properties and they have been widely analyzed in the literature. Some of them are the monotonicity, the quasi-concavity and also the homogeneity of Grade 1 that are present in this functional form. One of its potential advantages is that the properties are easily satisfied when aggregated data are used such as countries, states or urban areas (see, for example, Chambers [33]; Greene [34]). Equation (1) is used in its logarithmic transformation:

$$
\ln (f(q))=\ln \alpha_{0}+\sum_{k=1}^{K} \beta_{k} \ln \left(x_{k}\right), \text { for all } \beta_{k}>0
$$

where $f(q)$ is a measure of production, $x_{k}$ represents the inputs and $\beta_{k}$ are $k$ coefficients to be estimated. Greene [35] and [34] considers that an efficient estimation of this function is possible through a regression equation by 
ordinary least squares, because the approximation to non-linear regression is quite acceptable.

The deposition of information for cross-section and time dimensions simultaneously, in addition to some refined econometric methods, allows us to achieve increased flexibility of this logarithmic function. We specify the main infrastructure variables in Equation (2) as water, drainage, airports, roads, education and investment; moreover, if a panel structure is considered and the variables are taken in first differences, the model acquires the next expression:

$$
\Delta \ln (y)_{i, t}=\alpha_{0}+\beta_{1} \Delta \ln (L)_{i, t}+\beta_{2} \Delta \ln (P C)_{i, t}+\beta_{3} \Delta \ln (H C)_{i, t}+\sum \gamma_{j}(\text { INFRA })_{i, t}+\varepsilon_{i, t}
$$

where $\Delta$ indicates a variable in first differences, $i=1, \cdots, n ; t=1, \cdots, T$ and $\varepsilon_{i t}$ is the stochastic error term, $n$ is the total number of cross-sections and $T$ is the total number of temporal observations in the panel. The dependent variable " $y$ " is the per capita product, " $L$ " is the number of workers, " $P C$ " is the gross investment in physical capital and " $H C$ " is the human capital. The set of $\gamma$ coefficients in the equation represents the rest of the infrastructure variables to be estimated: water, drainage, roads and airports, among others. Considering first differences, it is possible to reduce the autocorrelation of first order that is regularly present in structures of quinquennial or annual data.

In the estimation of Equation (3), a panel of 71 Mexican cities (urban areas) is available for 1985 to 2008 and for quinquennial periods. Moreover, up to two lags of the independent variables and not only the contemporaneous values are used to avoid contemporaneous correlation. The empirical results indicate substantial improvements of the estimates. These also consider the comments in several works that infrastructure investments in fact have a lagged effect on economic growth (Feltenstein and Ha [27]; Lächler and Aschauer [31]; Noriega and Fontela [30]). Following these ideas, an empirical production function for the urban areas of Mexico can be as follows:

$$
\begin{aligned}
\Delta \ln (y)_{i, t}= & \alpha_{0}+\beta_{1} T E N D+\beta_{2} \Delta \ln (L)_{i, t}+\beta_{3} \Delta \ln (P C)_{i, t}+\beta_{4} \Delta \ln (H C)_{i, t} \\
& +\beta_{5} \Delta\left(\ln \left(H C^{*} A I R\right)+\gamma_{1} I N F R A_{-} \text {WATER }_{i, t}+\gamma_{2} \text { INFRA_DRA }_{i, t}\right. \\
& +\gamma_{3} I N F R A_{-} E L E C_{i, t}+\gamma_{4} I_{\text {INFRA_ROADS }}+v_{i, t}
\end{aligned}
$$

where, as before, $\Delta$ denotes a variable in first differences, $i=1, \cdots, 71 ; t=1, \cdots, 6$ and $v_{i, t}$ is the stochastic error term; moreover, some control variables are included and they deserve an explanation. The dependent variable $\ln (y)$ is the per capita product at constant prices for each urban area and temporal period; TEND is a linear trend, representing the change in the production function, and it is interpreted as a proxy for technological progress; $L$ is the number of workers; $P C$ is the stock of physical capital; $H C$ is the human capital measured as the percentage of the population aged between 12 and 15 years that has matriculated in secondary school; and $H C^{*} A I R$ is an indicator that seeks to capture whether urban areas with airports have some advantage reflected in the economic growth, where AIR takes the value of 1 if the city has an airport and 0 otherwise. They are also considered as interactive variables to test whether cities with airports have better performance in terms of human capital that is reflected in the economic growth. Finally, the explicative variables defined as INFRA_WATER, INFRA_ DRA, INFRA_ELEC and INFRA_ROADS are indicators of the infrastructure for domestic water, electric supply and roads. They seek to capture the impact of those endowments on economic growth.

The evidence is supported by three dependent variables in (4): The per capita product, the labor product and the product per person aged at least 15 years. The idea is to find out whether the empirical relationship is robust to several ways of measuring economic growth. In addition, Equation (4) is essayed for four scenarios: The overall sample, urban areas of greater and lower income and capital cities of the Mexican states. Finally, up to two lags of the variables are taken into account with the aim of capturing the lagged effects on economic growth. The inclusion of these lags also reduces some collinearity problems that regularly arise in cross-sectional regressions.

\section{Variables, Data and Samples}

The three basic sources of data are quinquennial economic censuses collected and published by the National Institute of Statistics and Geography (INEGI, the official Mexican institute of statistics), the national council of population (CONAPO) and the annual statistics published by INEGI [36]. Therefore, the aggregated value, labor $(L)$, fixed investment in physical capital $(P C)$ and total product in real prices come from those institutes. For 
human capital $(H C)$, a proxy for education is used: the matriculated students in secondary school as a percentage of the population, as in Barro and Lee [37], for an international comparison of education. For the Mexican case, this proxy is found to have better results in economic growth studies (see Díaz-Bautista [38]; Ocegueda-Hernández and Plascencia López [39]; Mayer-Foulkes [40], among others).

The information on airports comes from the annual statistics of INEGI (2010) and it is considered as a binary variable that takes the value of 1 if the city has an airport and 0 otherwise. Finally, physical infrastructures-water, drainage and electricity — are built as indices for each thousand inhabitants of 15 years old and more. For the road infrastructure (INFRA_ROADS), a synthetic index was elaborated through the Biehl [41] methodology. For each region, the author weights the system of main, secondary and tertiary roads as follows:

$$
I_{i, r}=\left(\frac{1}{n}\right) \cdot \sum S_{j, r}
$$

where $I_{i, r}$ is the Biehl index for category $i$ and region $r$ and $S_{j, r}$ is an indicator of the $j$ subcategory included in the $i$ class (see Biehl [41]).

In 2010, the set of 71 cities integrated into this study accounted for 64 percent of the total population of the country and 87 percent of the total national product. An analysis of productivity highlights the northern and central cities as being more productive, while some less productive cities are concentrated mainly in the south. Figure 1 shows the geographical location of the 71 urban areas of this study. The central zone has more localities.

On the other hand, Figure 2 and Figure 3 show the location of richer and poorer cities, while Figure 4 shows the location of the capital cities. This sample is justified by the fact that capital cities often tend to concentrate more on infrastructure because they also host the state government and many federal dependencies.

\section{Results}

The overall regressions from the panel data structure are shown in Tables 1-4. They correspond to the results for each designed sample. A couple of general comments arise from those empirical estimates. First, the statistics highlight the positive impacts of the infrastructure on the economic growth throughout the period, suggesting the presence of strong extensive growth. The overall regression coefficients are statistically significant; moreover, they are harmonized with the theoretical expectation on the infrastructure-economic growth relationship. The

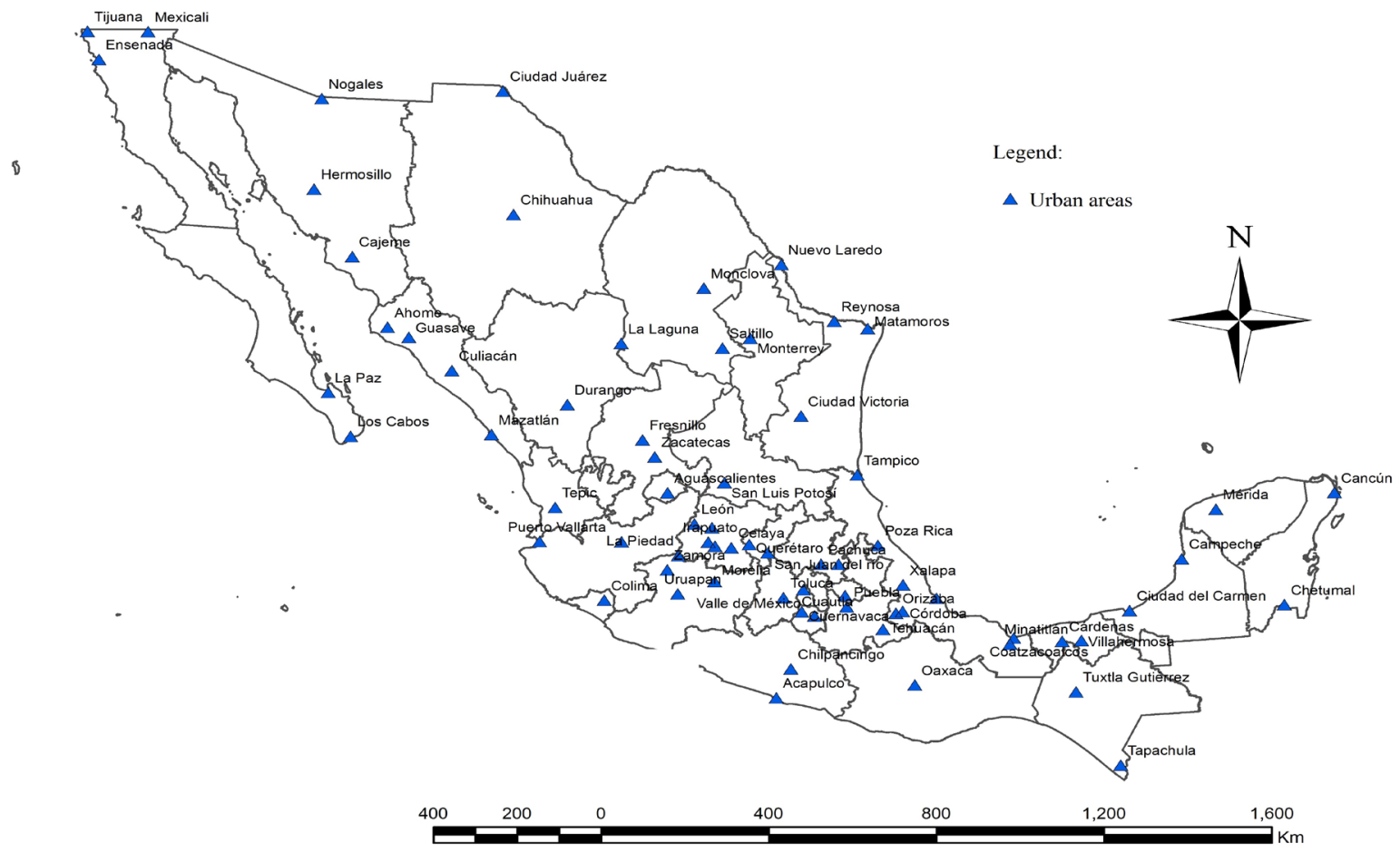

Figure 1. Geographical location of the urban areas overall sample. Source: Own elaboration. 


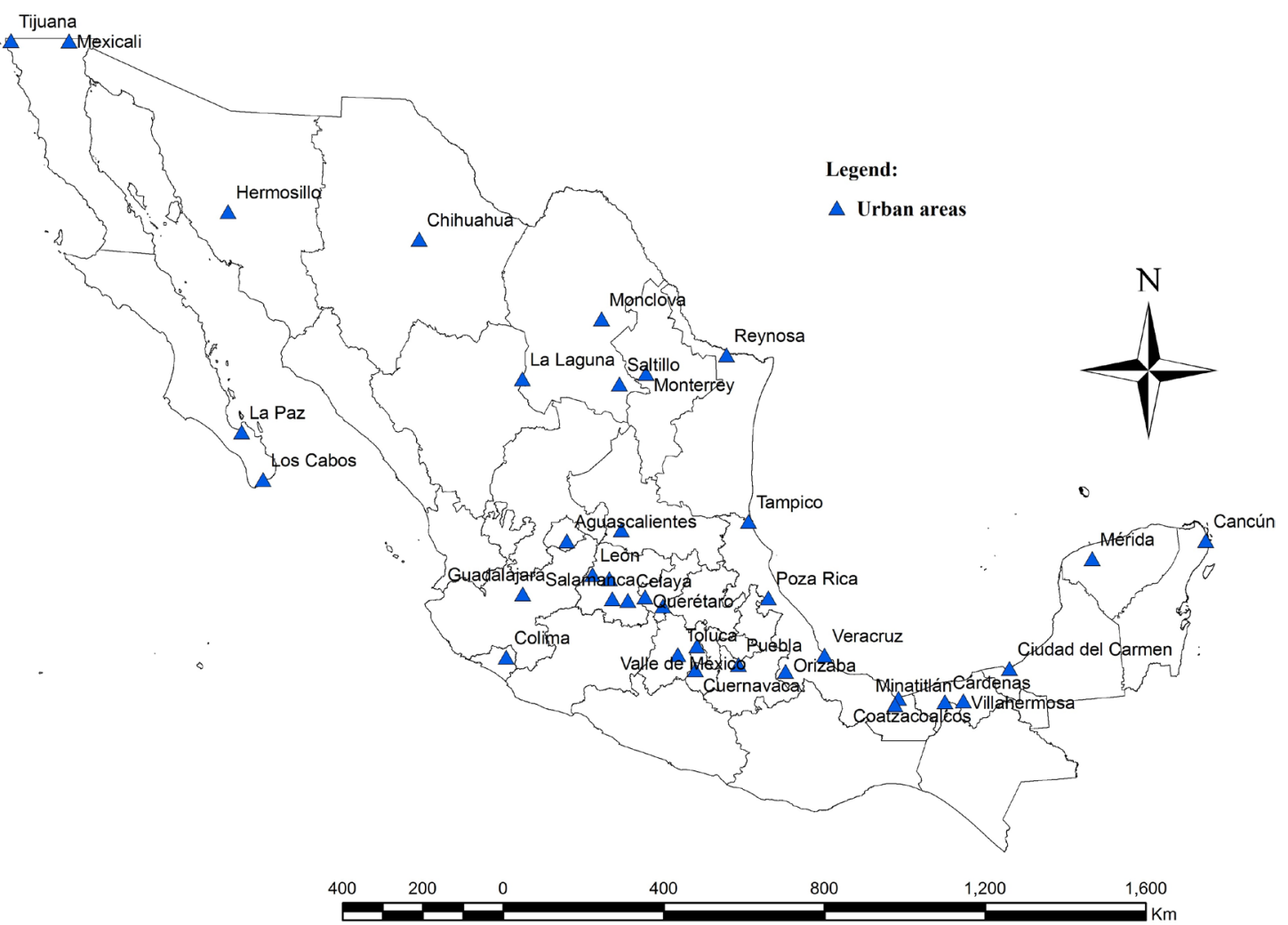

Figure 2. Geographical location of the greater-income urban areas. Source: Own elaboration.

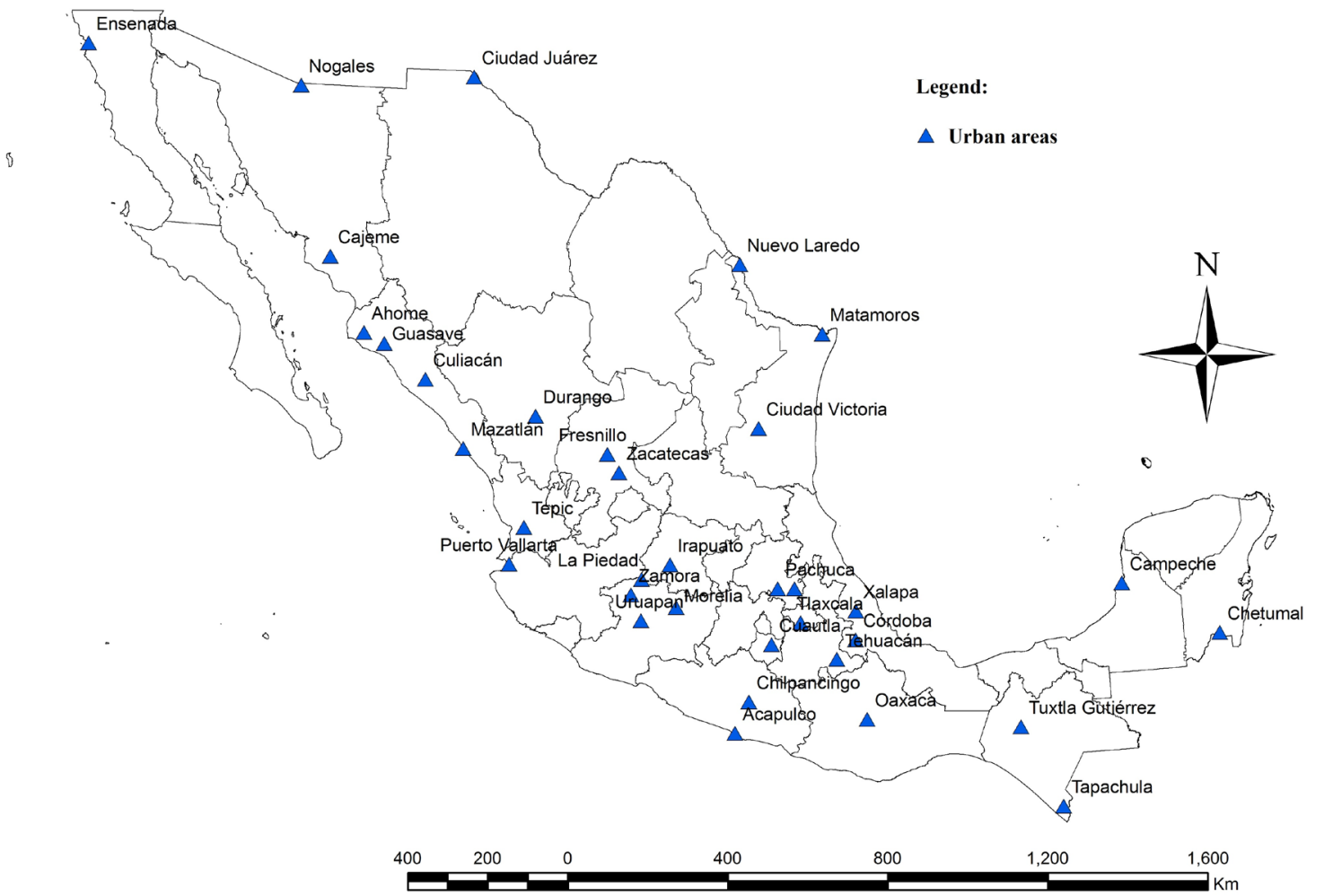

Figure 3. Geographical location of the lower-income urban areas. Source: Own elaboration. 


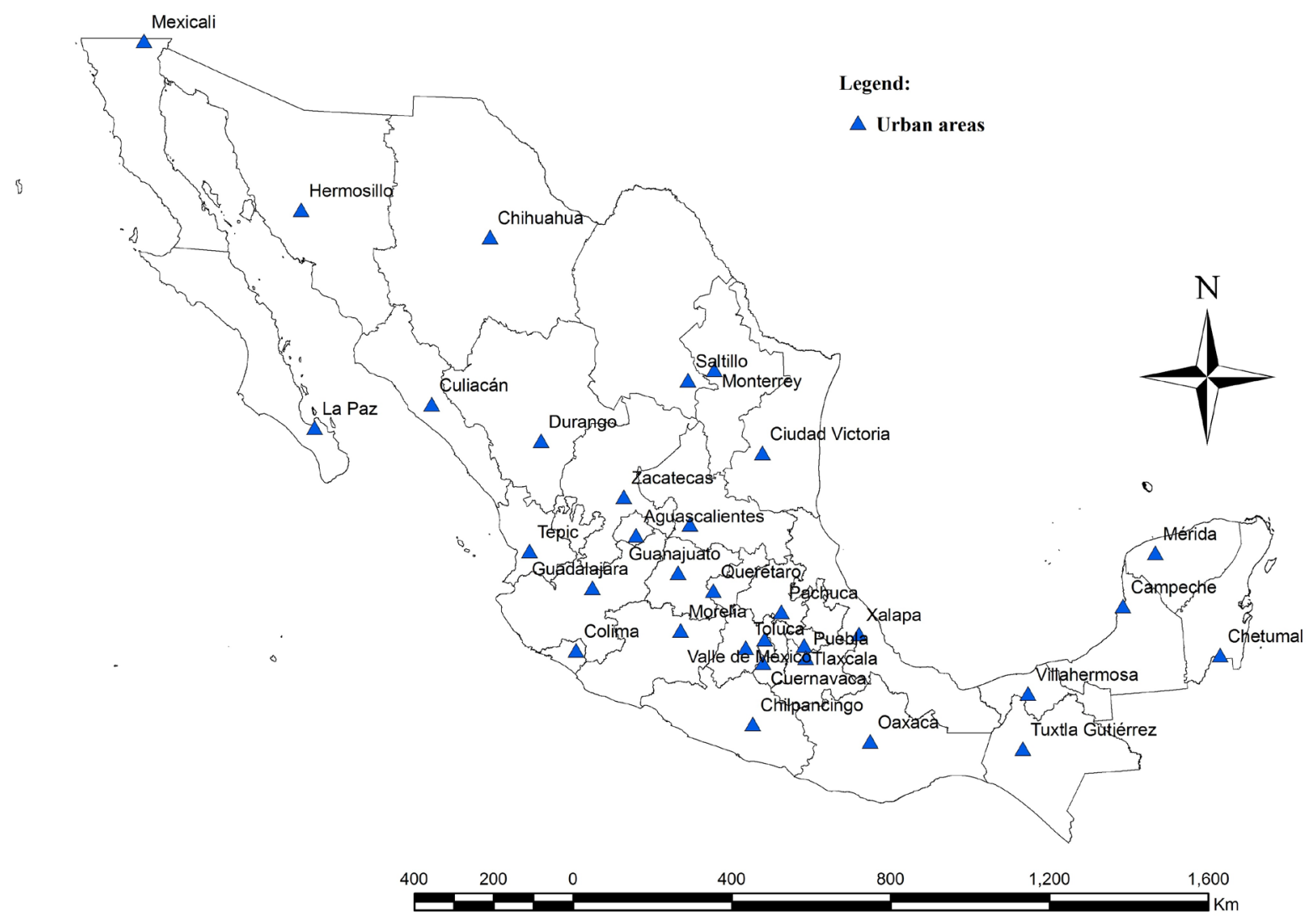

Figure 4. Geographical location of the capital cities. Source: Own elaboration.

adjusted $\mathrm{R}^{2}$ is quite acceptable because it is estimated at between 53 percent and 85 percent. Second, as expected, the impacts of the explicative variables are different for each sample. To construct a more adequate empirical specification, the Bayesian information criterion (BIC) was used. Differently from other criteria, the BIC imposes more penalties on specifications with more regressors, avoiding in this way an artificial increment of the adjustment of the model (Greene [34]; Gujarati and Porter [42]). This observation is especially important in situations in which the sample is quite heterogeneous, such as is expected in the infrastructure-economic growth analysis.

The possible serial autocorrelation was reduced by including a linear trend term. In all the regressions, this coefficient is highly significant, indicating a strong temporal relationship among the variables. Moreover, the infrastructure investment effects are best captured if lagged values of the economic growth inputs are contemplated in the model, an observation that can be more interesting in essays with the features that present the infrastructure and economic growth variables. In these cases, a non-linear relationship often describes their conduct more precisely, because the infrastructure investments also need to mature before they can impact on the economic growth.

To understand the estimated impacts better, we adopt a horizontal analysis, which consists of following the same variable across the several tables. For example, for the entire sample, it is possible to see positive and highly significant effects of labor. The labor input effects are not immediate but they tend to affect the economic growth after one period-equal to five years in our database. A few cases are found with significant current effects, as in the greater-income urban areas and capital cities samples, although at the start they are estimated with a negative sign, indicating that they initially tend to inhibit the economic growth. We can provide an explanation for this conduct. The hiring of new workers absorbs resources that could have been directed towards generating major growth, so initially it inhibits the economic growth. Only after some time do the new workers start to obtain returns with positive impacts, because augmenting the labor productivity also takes some time.

Physical capital is estimated as positive and highly significant, as expected, even after two periods of carrying 
Table 1. Results for the urban areas overall sample.

\begin{tabular}{|c|c|c|c|}
\hline \multirow[b]{2}{*}{ Explicative variables } & \multirow[b]{2}{*}{ Y1 } & \multicolumn{2}{|c|}{ Dependent variable } \\
\hline & & Y2 & Y3 \\
\hline \multirow[t]{2}{*}{ CONSTANT } & $-1.9312^{* * *}$ & $-1.8189^{* * *}$ & $-1.6404^{* * *}$ \\
\hline & $(0.2118)$ & $(0.1980)$ & $(0.2211)$ \\
\hline \multirow[t]{2}{*}{ TEND } & $0.4301^{* * *}$ & $0.3783^{* * *}$ & $0.3685^{* * *}$ \\
\hline & $(0.0473)$ & $(0.0423)$ & $(0.0475)$ \\
\hline \multirow[t]{2}{*}{$\Delta \ln (L)[-1]$} & $0.3437^{* * *}$ & $0.4068^{* * *}$ & $0.3504^{* * *}$ \\
\hline & $(0.1224)$ & $(0.1036)$ & $(0.1157)$ \\
\hline \multirow[t]{2}{*}{$\Delta \ln (P C)$} & & & $0.0097^{* *}$ \\
\hline & & & $(0.0049)$ \\
\hline \multirow[t]{2}{*}{$\Delta \ln (P C)[-2]$} & $0.0603^{* * *}$ & $0.0374^{* * *}$ & $0.0497^{* * *}$ \\
\hline & $(0.0112)$ & $(0.0097)$ & $(0.0108)$ \\
\hline \multirow[t]{2}{*}{$\Delta \ln (H C)[-1]$} & $0.3824^{* *}$ & $0.4325^{* * *}$ & $0.3249^{* *}$ \\
\hline & $(0.1534)$ & (0.1298) & $(0.1472)$ \\
\hline \multirow[t]{2}{*}{$\Delta \ln \left(H C^{*} A E R\right)$} & $0.7000^{* * *}$ & $0.4995^{* * *}$ & $0.5111^{* *}$ \\
\hline & $(0.1986)$ & $(0.1755)$ & $(0.2010)$ \\
\hline \multirow[t]{2}{*}{ INFRA_WATER [-1] } & $-0.0237^{*}$ & -0.0191 & $-0.0223^{*}$ \\
\hline & $(0.0145)$ & $(0.0123)$ & $(0.0137)$ \\
\hline \multirow[t]{2}{*}{ INFRA_WATER [-2] } & & & $0.0236^{*}$ \\
\hline & & & $(0.0139)$ \\
\hline \multirow[t]{2}{*}{ INFRA_DRA [-1] } & & $-0.7568^{* * *}$ & $-0.8928^{* * *}$ \\
\hline & & $(0.2730)$ & $(0.3046)$ \\
\hline \multirow[t]{2}{*}{ INFRA_DRA [-2] } & $0.2525^{*}$ & $0.5499^{* * *}$ & $0.6909^{* * *}$ \\
\hline & $(0.1601)$ & $(0.1921)$ & $(0.2144)$ \\
\hline \multirow[t]{2}{*}{ INFRA_ROADS } & $0.3006^{* *}$ & $0.2798^{* *}$ & $0.2663^{*}$ \\
\hline & $(0.1464)$ & $(0.1237)$ & $(0.1381)$ \\
\hline Adjusted $\mathrm{R}^{2}$ & 0.53 & 0.59 & 0.56 \\
\hline \multicolumn{2}{|c|}{ Observations } & \multicolumn{2}{|c|}{$213(\mathrm{~T}=3 ; \mathrm{N}=71)$} \\
\hline
\end{tabular}

Notes: Figures in square brackets (on the right-hand side of the name of variables) indicate the number of lags. Standard errors in parentheses. ${ }^{* * *},{ }^{* *}$ and ${ }^{*}$ indicate significance at $1 \%, 5 \%$ and $10 \%$, respectively. Y1 = per capita product, Y2 = per worker product and Y3 = product per person older than 15 years. Source: Own estimates.

out the investments. In addition, the current values of this factor are estimated as being highly significant for the economic growth of the urban areas, unlike the other factors, for which the contemporaneous effects are not significant. The impacts on economic growth of these features are visible for the overall, greater-income and capital cities samples. In the particular case of the lower-income sample, the results are inverted, indicating a lack of capital investment in these areas. However, this is a characteristic that is present in poor or economically lagging areas.

The general finding for human capital highlights no immediate returns. The current value is significant in none of the samples; however, the first lag is positive and significant for the overall, greater-income and capital 
Table 2. Results for the greater-income urban areas sample.

\begin{tabular}{|c|c|c|c|}
\hline \multirow[b]{2}{*}{ Explicative variables } & \multicolumn{3}{|c|}{ Dependent variable } \\
\hline & Y1 & Y2 & Y3 \\
\hline \multirow[t]{2}{*}{ CONSTANT } & $-1.6797^{* * *}$ & $-1.5089^{* * *}$ & $-1.4434^{* * *}$ \\
\hline & $(0.2768)$ & $(0.2742)$ & $(0.2776)$ \\
\hline \multirow[t]{2}{*}{ TEND } & $0.4138^{* * *}$ & $0.3640^{* * *}$ & $0.3076^{* * *}$ \\
\hline & $(0.0788)$ & $(0.0655)$ & $(0.0699)$ \\
\hline \multirow[t]{2}{*}{$\Delta \ln (L)$} & & $-0.5604^{* * *}$ & \\
\hline & & $(0.1507)$ & \\
\hline \multirow[t]{2}{*}{$\Delta \ln (L)[-1]$} & & $0.4067^{* * *}$ & \\
\hline & & $(0.1241)$ & \\
\hline \multirow[t]{2}{*}{$\Delta \ln (P C)$} & $0.0369^{* * *}$ & $0.0286^{* * *}$ & $0.0412^{* * *}$ \\
\hline & $(0.0092)$ & $(0.0071)$ & $(0.0091)$ \\
\hline \multirow[t]{2}{*}{$\Delta \ln (P C)[-2]$} & $0.0574^{* * *}$ & $0.0418^{* * *}$ & $0.0568^{* * *}$ \\
\hline & $(0.0113)$ & $(0.0082)$ & $(0.0112)$ \\
\hline \multirow[t]{2}{*}{$\Delta \ln (H C)[-1]$} & $0.5276^{*}$ & $0.5588^{* *}$ & $0.7355^{* *}$ \\
\hline & $(0.2872)$ & $(0.2220)$ & $(0.2905)$ \\
\hline \multirow[t]{2}{*}{$\Delta \ln (H C)[-2]$} & $-0.7146^{* *}$ & $-0.5987^{* * *}$ & \\
\hline & $(0.2747)$ & $(0.2131)$ & \\
\hline \multirow[t]{2}{*}{$\Delta \ln \left(C H^{*} A E R\right)$} & & & $0.5823^{*}$ \\
\hline & & & $(0.3126)$ \\
\hline \multirow[t]{2}{*}{ INFRA_WATER [-1] } & & $-0.0389^{*}$ & $-0.0496^{*}$ \\
\hline & & $(0.0207)$ & $(0.0273)$ \\
\hline \multirow[t]{2}{*}{ INFRA_WATER [-2] } & $0.0842^{* * *}$ & $0.0655^{* * *}$ & $0.0488^{*}$ \\
\hline & $(0.0286)$ & $(0.0216)$ & $(0.0274)$ \\
\hline \multirow[t]{2}{*}{ INFRA_DRA [-2] } & $0.3237^{*}$ & & $0.3537^{*}$ \\
\hline & $(0.1869)$ & & $(0.1847)$ \\
\hline \multirow[t]{2}{*}{ INFRA_ELEC } & $0.7271^{* *}$ & $0.4642^{*}$ & $0.6531^{*}$ \\
\hline & (0.3309) & $(0.2534)$ & $(0.3301)$ \\
\hline \multirow[t]{2}{*}{ INFRA_ROADS } & $0.5408^{* * * *}$ & $0.2668^{*}$ & $0.4731^{* * *}$ \\
\hline & $(0.1818)$ & $(0.1358)$ & (0.1799) \\
\hline Adjusted $\mathrm{R}^{2}$ & 0.68 & 0.77 & 0.67 \\
\hline Observations & & $108(\mathrm{~T}=3 ;$ & \\
\hline
\end{tabular}

Notes: See notes of Table 1. Source: Own estimates.

cities samples. In addition, for the greater-income sample, the second lag effect is estimated as significant but negative, reflecting decreasing returns on economic growth for those urban areas, matching the theory on decreasing returns.

The interactive variables between human capital and airports have the purpose of picking up the potential impacts from the education level of those urban areas with an airport infrastructure. In this respect, the results suggest substantial importance of these effects for the Mexican urban growth. For all the samples, the regressions show positive and highly significant coefficients. For the capital cities sample, this estimated coefficient is high and very close to the unit, suggesting great absorption of human capital from airport services. 
Table 3. Results for the lower-income urban areas sample.

\begin{tabular}{|c|c|c|c|}
\hline \multirow[b]{2}{*}{ Explicative variables } & \multicolumn{3}{|c|}{ Dependent variable } \\
\hline & Y1 & Y2 & Y3 \\
\hline \multirow[t]{2}{*}{ CONSTANT } & $-1.7470^{* * *}$ & $-1.9460^{* * *}$ & $-1.7428^{* * *}$ \\
\hline & $(0.3005)$ & $(0.2821)$ & (0.2989) \\
\hline \multirow[t]{2}{*}{ TEND } & $0.3724^{* * *}$ & $0.3757^{* * *}$ & $0.3627^{* * *}$ \\
\hline & $(0.0557)$ & $(0.0523)$ & $(0.0554)$ \\
\hline \multirow[t]{2}{*}{$\Delta \ln (L)[-1]$} & $0.2399^{*}$ & $0.3260^{* *}$ & $0.2485^{*}$ \\
\hline & (0.1369) & $(0.1285)$ & $(0.1362)$ \\
\hline \multirow[t]{2}{*}{$\Delta \ln \left(H C^{*} A E R\right)$} & $0.5184^{* *}$ & $0.4998^{* *}$ & $0.5421^{* *}$ \\
\hline & $(0.2369)$ & $(0.2224)$ & $(0.2357)$ \\
\hline \multirow[t]{2}{*}{ INFRA_DRA } & $2.4574^{* * *}$ & $2.4794^{* * *}$ & $2.4522^{* * *}$ \\
\hline & $(0.9124)$ & $(0.8564)$ & $(0.9078)$ \\
\hline \multirow[t]{2}{*}{$I N F R A \_D R A[-1]$} & $-2.1223^{* * *}$ & $-1.7114^{* * *}$ & $-2.0831^{* * *}$ \\
\hline & $(0.5091)$ & $(0.4778)$ & $(0.5064)$ \\
\hline \multirow[t]{2}{*}{$I N F R A \_D R A[-2]$} & $1.2223^{* * *}$ & $0.8939^{* * *}$ & $1.1796^{* * *}$ \\
\hline & $(0.3185)$ & $(0.2989)$ & $(0.3168)$ \\
\hline \multirow[t]{2}{*}{ INFRA_ELEC [-2] } & $0.2009^{*}$ & $0.2519^{* *}$ & $0.2065^{* *}$ \\
\hline & -0.1058 & $(0.0993)$ & $(0.1052)$ \\
\hline Adjusted $\mathrm{R}^{2}$ & 0.57 & 0.58 & 0.57 \\
\hline Observations & \multicolumn{3}{|c|}{$105(\mathrm{~T}=3 ; \mathrm{N}=35)$} \\
\hline
\end{tabular}

Notes: See notes of Table 1. Source: Own estimates.

On the other hand, some infrastructure variables, such as the availability of water for human consumption, an electric supply, drainage and a road network, have also been driving the urban growth in Mexico. However, the estimated evidence is not as strong as that for the previously analyzed factors. Taking into account their statistical significance, they seem to be more sensitive to the sample size and also to the kind of dependent variable considered.

Increases are found in water for human consumption in the greater-income urban areas, capital cities and overall samples, meaning increments of rates of growth only after the second lag, while their current values are not relevant, together with a negative association from their first lags with growth-this is the result for the overall and greater-income samples. The extension of water for human consumption to an increasing number of inhabitants tends to improve the well-being conditions and, from a long-run point of view, increases the production. However, it is a process that takes places in stages with a lag. For example, the high cost of infrastructure public investment initially inhibits the economic growth, because an important amount of monetary resources are redirected with that objective. While those investments are recovered through more employment, production and private capital, their returns are not immediately reflected in growth. Such is the case of the lower-income sample, for which no evidence relating the water infrastructure to economic growth is found. A similar dynamic is highlighted by the drainage infrastructure. For those samples with a significant effect, it results as negative in its first lag and positive in the second one-see the overall, greater-income and lower-income samples.

Finally, only for two samples-overall and greater-income cities-is evidence on a significant effect of the road network on economic growth obtained. For both samples, the current value is positive and significant.

\section{Conclusions}

After an examination of the main results, it is possible to conclude that there is, indeed, a positive association between infrastructure and economic growth, such as is expected from the theory. The evidence also strongly 
Table 4. Results for the capital cities sample.

\begin{tabular}{|c|c|c|c|}
\hline \multirow[b]{2}{*}{ Explicative variables } & \multicolumn{3}{|c|}{ Dependent variable } \\
\hline & Y1 & Y2 & Y3 \\
\hline \multirow[t]{2}{*}{ CONSTANT } & $-2.4457^{* * *}$ & $-1.5983^{* * *}$ & $-2.3871^{* * *}$ \\
\hline & $(0.2834)$ & $(0.3533)$ & $(0.2765)$ \\
\hline \multirow[t]{2}{*}{ TEND } & $0.5005^{* * *}$ & $0.3309^{* * *}$ & $0.4619^{* * *}$ \\
\hline & $(0.0606)$ & $(0.0631)$ & $(0.0607)$ \\
\hline \multirow[t]{2}{*}{$\Delta \ln (L)$} & & $-0.7515^{* * *}$ & \\
\hline & & $(0.2215)$ & \\
\hline \multirow[t]{2}{*}{$\Delta \ln (L)[-1]$} & $0.5793^{* * *}$ & $0.5755^{* * *}$ & $0.6736^{* * *}$ \\
\hline & $(0.1538)$ & $(0.1477)$ & $(0.1572)$ \\
\hline \multirow[t]{2}{*}{$\Delta \ln (P C)$} & $0.0632^{* * *}$ & $0.0616^{* * *}$ & $0.0616^{* * *}$ \\
\hline & $(0.0204)$ & $(0.0182)$ & $(0.0198)$ \\
\hline \multirow[t]{2}{*}{$\Delta \ln (P C)[-2]$} & & $0.0514^{* *}$ & $0.0500^{*}$ \\
\hline & & $(0.0236)$ & $(0.0268)$ \\
\hline \multirow[t]{2}{*}{$\Delta \ln (H C)[-1]$} & $0.5862^{* * *}$ & $0.5028^{* * *}$ & $0.6256^{* * *}$ \\
\hline & $(0.2193)$ & $(0.1885)$ & $(0.2139)$ \\
\hline \multirow[t]{2}{*}{$\triangle \ln \left(H C^{*} A E R\right)$} & $0.8713^{* * *}$ & $0.5638^{* *}$ & $0.8851^{* * *}$ \\
\hline & $(0.2659)$ & $(0.2353)$ & $(0.2581)$ \\
\hline \multirow[t]{2}{*}{ INFRA_WATER } & $1.0043^{* * *}$ & $0.6238^{*}$ & $0.9832^{* * *}$ \\
\hline & $(0.3764)$ & & $(0.3655)$ \\
\hline \multirow[t]{2}{*}{ INFRA_WATER [-2] } & $-0.0990^{*}$ & & $-0.0960^{*}$ \\
\hline & $(0.0551)$ & & $(0.0535)$ \\
\hline Adjusted $\mathrm{R}^{2}$ & 0.61 & 0.69 & 0.62 \\
\hline Observations & & $(\mathrm{T}=3 ; \mathrm{N}=$ & \\
\hline
\end{tabular}

Notes: See notes of Table 1. Source: Own estimates.

suggests that the effects are not immediate and that it can take some time for them to return more growth for economies. This process seems to have some logic. Consider, for example, that any investment needs some time after being installed to generate employment, increase the productivity and thus speed the economic growth. In the meantime, the synergies that allow the extension of social and economic opportunities are generated.

The long-term effect just described agrees with previous research highlighting a lagged effect of infrastructure investments on growth. For example, in the particular case of Mexico, Noriega and Fontela [30] consider up to 11 lag years to obtain significant effects of infrastructures on the national real production. For the Mexican urban areas level, we have reported a similar temporal effect dynamic because for some factors two lags- - that is, ten years-were necessary to reach the best estimates.

In terms of economic policy, the conclusions about the importance of lagged infrastructure effects mean that Mexico needs an active industrial policy to follow growth. In the present day, the nation has abandoned any industrial policy of public investment, which in other years meant great rates of growth. However, this recommendation of industrial policy must be promoted, creating mechanisms of regional equality. The open trade era has resulted in the internal relocation of some production factors among the several regions of the country, such as human capital, concentrating on some of them and diminishing others. The public expenditure constitutes an adequate vehicle for major regional cohesion that deserves more consideration in the elaboration of regional 
policies.

This research can be extended with techniques of unit roots and cointegration with stochastic panels between infrastructure and economic growth. Specifically, the stochastic scope could complement the evidence on the intricate relationship of these variables in regional and urban contexts.

\section{Acknowledgements}

The authors acknowledge the financial support from the Autonomous University of Coahuila (V. German-Soto) and Autonomous University of Ciudad Juárez (H. A. Barajas Bustillos) and useful comments of two anonymous referees. Also, this work benefited from the suggestions made by the assistants to the seminar "Actividadeconómica y empleo. Un análisis sectorial en México y sus regiones" was held in the building of Facultad de Economía de la Universidad Autónoma del Estado de México, Toluca, November 18th, 2014.

\section{References}

[1] Aschauer, D. (1989) Is Public Expenditure Productive? Journal of Monetary Economics, 23, 177-200. http://dx.doi.org/10.1016/0304-3932(89)90047-0

[2] Aschauer, D. (2000) Public Capital and Economic Growth: Issues of Quantity, Finance, and Efficiency. Economic Development and Cultural Change, 48, 391-406. http://dx.doi.org/10.1086/452464

[3] Hirschman, A. (1973) La estrategia del desarrollo económico. Fondo de Cultura económica, México.

[4] Nijkamp, P. and Ubbels, B. (1999) Infrastructure, Suprastructure and Ecostructure: A Portfolio of Sustainable Growth Potentials. Faculteit der Economische Wetenschappenen Econometric. Research Memorandum, 1999-51, 1-18.

[5] Organization for Economic Co-Operation and Development (OECD) (2002) Impact of Transport Infrastructure Investment on Regional Development. OECD, Paris.

[6] Chiquiar, D. (2005) Why Mexico’s Regional Income Convergence Broke Down. Journal of Development Economics, 77, 257-275. http://dx.doi.org/10.1016/j.jdeveco.2004.03.009

[7] Buitrago, R. (2009) Reformas comerciales (apertura) en América Latina: Revisando sus impactos en el crecimiento y el desarrollo. Investigación y Reflexión, 17, 119-131.

[8] Garduño R. and Rafael (2014) La apertura comercial y su efecto en la distribución regional de México. El Trimestre Económico, 81, 413-439.

[9] Calderón Villarreal, C. (2006) Apertura económica, salarios y migración internacional. Análisis Económico, 21, 167187.

[10] Ocegueda-Hernández, J.M. (2007) Apertura comercial y crecimiento económico en las regiones de México. Investigación Económica, 76, 89-137.

[11] De Hoyos, R. and Lustig, N. (2009) Apertura Comercial, Desigualdad y Pobreza. El Trimestre Económico, 76, 283328.

[12] Barro, R. (1990) Government Spending in a Simple Model of Endogenous Growth. Journal of Political Economy, 98, 103-125. http://dx.doi.org/10.1086/261726

[13] Lall, S.V. (2007) Infrastructure and Regional Growth, Growth Dynamics and Policy Relevance for India. Annals of Regional Science, 41, 581-599. http://dx.doi.org/10.1007/s00168-006-0112-4

[14] Puga, D. (2002) European Regional Policies in Light of Recent Location Theories. Journal of Economic Geography, 2, 373-406. http://dx.doi.org/10.1093/jeg/2.4.373

[15] Nurske, R. (1953) Problems of Capital Formation in Underdeveloped Countries. Basil Blackwell, Oxford.

[16] Hirschman, A. (1958) The Strategy of Economic Development. Westview Press Inc., Boulder.

[17] Nadiri, I. (1970) International Studies of Factor Inputs and Total Factor Productivity: A Brief Survey. Review of Income and Wealth, 18, 129-148. http://dx.doi.org/10.1111/j.1475-4991.1972.tb00855.x

[18] Sánchez-Robles, B. (1998) Infrastructure Investment and Growth: Some Empirical Evidence. Contemporary Economic Policy, 16, 98-108. http://dx.doi.org/10.1111/j.1465-7287.1998.tb00504.x

[19] Evans, P. and Karras, G. (1994) Is Government Capital Productive? Evidence from a Panel of Seven Countries. Journal of Macroeconomics, 16, 271-279. http://dx.doi.org/10.1016/0164-0704(94)90071-X

[20] Holtz-Eakin, D. and Schwartz, A.E. (1995) Spatial Productivity Spillovers from Public Infrastructure: Evidence from State Highways. NBER Working Paper Series, 2, 459-468.

[21] Devarajan, S., Swaroop, V. and Zou, H.F. (1996) The Composition of Public Expenditure and Economic Growth. Journal of 
Monetary Economics, 37, 313-344.

[22] Otto, G.D. and Voss, G.M. (1996) Public Capital and Private Production in Australia. Southern Economic Journal, 62, 723-738. http://dx.doi.org/10.2307/1060890

[23] Zhang, X. (2008) Transport Infrastructure, Spatial Spillover and Economic Growth: Evidence from China. Frontiers of Economics in China, 3, 585-597. http://dx.doi.org/10.1007/s11459-008-0029-1

[24] Mizutani, F. and Tanaka, T. (2010) Productivity Effects and Determinants of Public Infrastructure Investment. Annals of Regional Science, 44, 493-521. http://dx.doi.org/10.1007/s00168-008-0279-y

[25] Pereira, A.M. and Andraz, J.M. (2012) On the Regional Incidence of Highway Investments in the USA. Annals of Regional Science, 48, 819-838. http://dx.doi.org/10.1007/s00168-010-0409-1

[26] Herrerías, M.J. and Orts, V. (2012) Equipment Investment, Output and Productivity in China. Empirical Economics, 42, 181-207. http://dx.doi.org/10.1007/s00181-010-0418-z

[27] Feltenstein, A. and Ha, J. (1995) The Role of Infrastructure in Mexican Economic Reform. World Bank Economic Review, 9, 287-304. http://dx.doi.org/10.1093/wber/9.2.287

[28] Fuentes, N.A. (2003) Crecimiento económico y desigualdades regionales en México: El impacto de la infraestructura. Región y Sociedad, 15, 81-103.

[29] Fuentes, N.A. and Mendoza Cota, J.E. (2003) Infraestructura pública y convergencia regional en México, 1980-1998. Comercio Exterior, 53, 178-187.

[30] Noriega, A. and Fontela, M. (2007) La infraestructura y el crecimiento económico en México. El Trimestre Económico, 74, 885-900.

[31] Lächler, U. and Aschauer, D. (1998) Public Investment and Economic Growth in Mexico. The World Bank Policy Research, Working Paper No. 1964, 17-18.

[32] Holtz-Eakin, D. (1994) Public-Sector Capital and the Productivity Puzzle. Review of Economics and Statistics, 76, 1221. http://dx.doi.org/10.2307/2109822

[33] Chambers, R.G. (1988) Applied Production Analysis. A Dual Approach. Cambridge University Press, New York.

[34] Greene, W.H. (2008) Econometric Analysis. Pearson Prentice Hall, Upper Saddle River.

[35] Greene, W.H. (1999) Análisis econométrico. Prentice Hall, Madrid.

[36] INEGI (2010) Estadísticas históricas de México, tomos I y II. INEGI, Aguascalientes.

[37] Barro, R. and Lee, J.W. (1993) International Comparisons of Educational Attainment. NBER Working Paper Series, $1-47$.

[38] Díaz-Bautista, A. (2000) Convergence and Economic Growth in Mexico. Frontera Norte, 13, 85-110.

[39] Ocegueda-Hernández, J.M. and Plascencia López, G. (2004) Crecimiento económico en la región fronteriza de México y Estados Unidos: Una contrastación empírica de la hipótesis de convergencia. Frontera Norte, 16, 7-31.

[40] Mayer-Foulkes, D. (2007) Fallas de mercado en capital humano. La trampa intergeneracional de la pobreza en México. El Trimestre Económico, 74, 543-614.

[41] Biehl, D. (1988) Las infraestructuras y el desarrollo regional. Papeles de Economía Española, 35, 293-310.

[42] Gujarati, D.N. and Porter, D.C. (2010) Econometría. McGraw-Hill, México. 
Scientific Research Publishing (SCIRP) is one of the largest Open Access journal publishers. It is currently publishing more than 200 open access, online, peer-reviewed journals covering a wide range of academic disciplines. SCIRP serves the worldwide academic communities and contributes to the progress and application of science with its publication.

Other selected journals from SCIRP are listed as below. Submit your manuscript to us via either submit@scirp.org or Online Submission Portal.
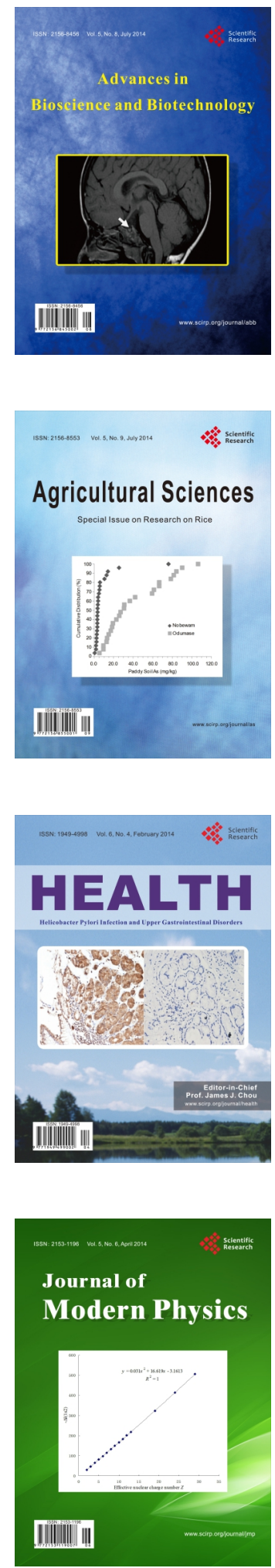
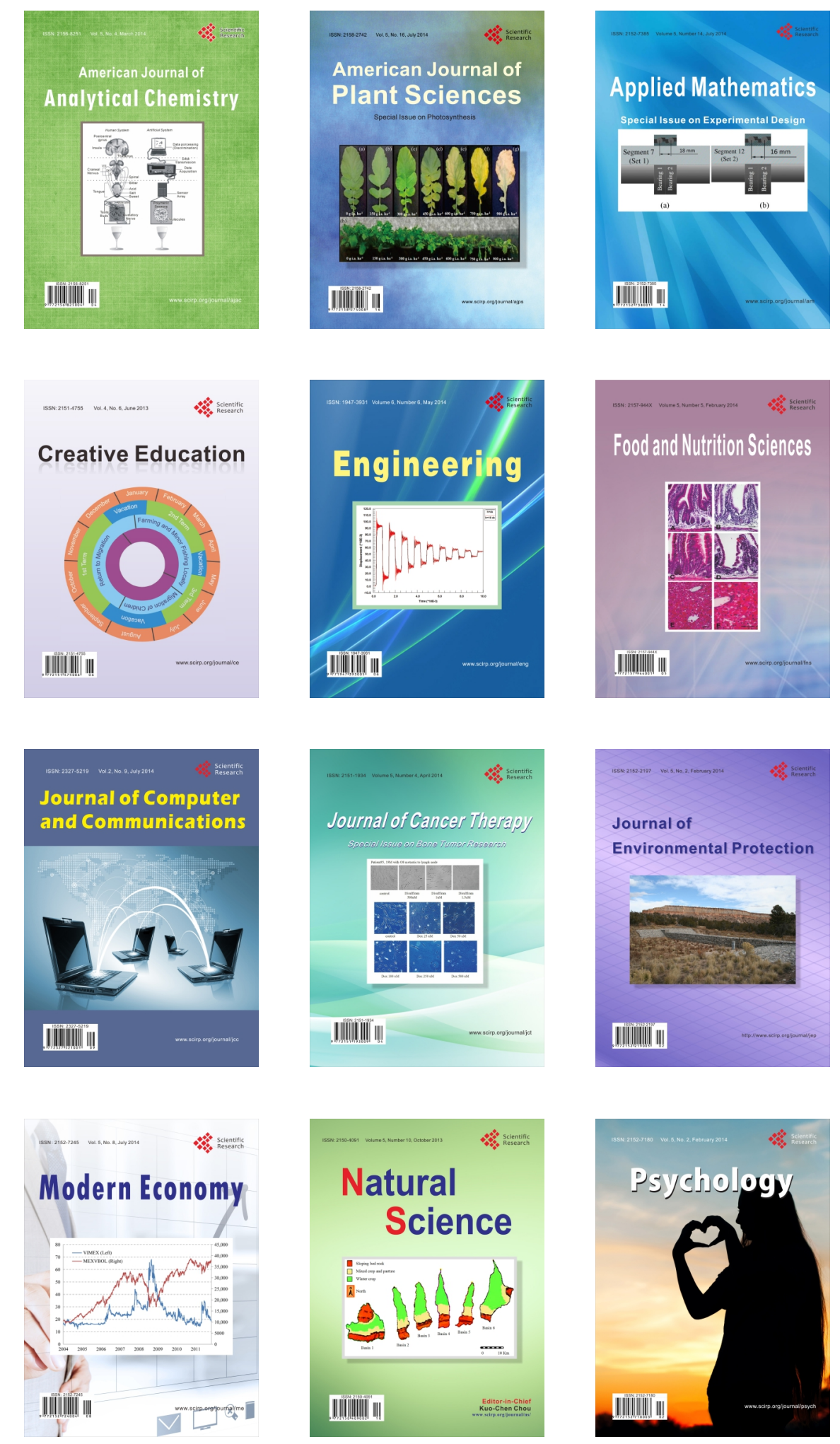